\title{
Hydrallantois in a female dog: a case report
}

\author{
[Hidroalantoide em cadela: relato de caso] \\ M.A.R. Feliciano, D.J. Cardilli, R.M. Crivelaro, E. Garrido, M.A.M. Silva, \\ T.L.L. Castanheira, W.R.R. Vicente \\ Faculdade de Ciências Agrárias e Veterinárias - UNESP/Jaboticabal - Jaboticabal, SP
}

\begin{abstract}
The aim of this study was to describe the clinical, ultrasound and histological findings of hydrallantois in a Pug bitch. On the $56^{\text {th }}$ day of pregnancy the patient presented pronounced abdominal distention, lethargy, anorexia and dyspnea. The ultrasound revealed the presence of abnormal fluid accumulation within the fetal membranes, especial in the allantois, which was incompatible with the $8^{\text {th }}$ week of pregnancy in bitches. The macroscopic exam during the C-section, distention of the fetal membranes and accumulation of fluid within the allantois was observed. The precise amount of liquid could not be assessed due to the surgical procedure. All neonates of our case report were normal at the initial physical exam. The histologic exam revealed normal placenta. In conclusion, clinical and ultrasound assessment were able to diagnose hydrallantois in a canine patient.
\end{abstract}

Keywords: female dog, hydrallantois

\section{RESUMO}

O objetivo do estudo foi descrever a sintomatologia clínica e achados ultrassonográficos e histopatológicos em um caso de hidroalantoide em cadela Pug. Aos $56^{\circ}$ dia de gestação, o animal apresentou distensão abdominal pronunciada, letargia, anorexia e dispneia. Por meio do exame ultrassonográfico, verificou-se o acúmulo anormal de líquido em membranas fetais, especialmente em alantoide, incompatível à oitava semana gestacional em cadelas. À inspeção macroscópica, verificou-se distensão de membranas fetais e acúmulo de líquido no interior do alantoide. A quantidade exata de líquido não pôde ser avaliada, devido ao procedimento cirúrgico. Todos os recém-nascidos do presente relato apresentavam-se normais ao exame físico inicial. Ao exame histopatológico, revelou-se placenta normal. Concluiu-se que a avaliação clínica e a ultrassonográfica foram capazes de diagnosticar a hidralantoide em uma cadela.

Palavras-chave: cadela, hidroalantoide

\section{INTRODUCTION}

Hydrops of fetal membranes is the large amount of fluid within the gravid uterus. The amniotic sac (hydramnios), the alantois (hydrallantois) or both may be affected. Hydrallantois more commonly affects the domestic species, which frequently occurs during the last third of pregnancy (Landim-Alvarenga, 2006; Jackson, 2006).

Recebido em 5 de abril de 2012

Aceito em 7 de maio de 2013

E-mail: marcusfeliciano@yahoo.com.br
Hydrallantois is rarely diagnosed and usually affects cows (Oehme, 1964), small ruminants (Loi et al., 2006), and also mares (Christensen et al., 2006). Such reproductive disorder is frequently associated to fetal hypoxia secondary to hemolytic diseases in humans. The physiopathology of hydrallantois is related to the reduction of placental vascularization, leading to metabolic changes in the placental tissue and fetal membranes and accumulation of fetal fluids. Such finding was observed in ovine clones, (Loi et al., 2006). Other causes are: fetal 
malformation, fetal hepatic or renal disorders (e.g., hydronephrosis) and umbilical cord torsion (Landim-Alvarenga, 2006; Jackson, 2006).

In bitches, the main gestational disorders include metabolic diseases (diabetes mellitus, gestational toxemia), infections (brucellosis and herpes virus infection) and non-infectious disturbances, such as trauma, genetic and fetal congenital disorders, inadequate nutrition, hypothyroidism and hypoluteoidism (Kustritz, 2006). Uterine and fetal membrane hydrops-related affections are seldom found in the canine specie.

Regarding the small animals practice, a report of hydrallantois in a Yorkshire Terrier was described (Smith, 1972). Therefore, due to the potentially rare nature of such clinical condition in companion animals, the aim of the current study was to describe the clinical, ultrasound and histological findings of hydrallantois in a Pug bitch.

\section{CASUISTRY}

The pregnancy of a female primiparous Pug dog aging two years and weighting approximately $9 \mathrm{~kg}$ was being followed using ultrasound scanning (gestational diagnosis, monitoring the development of concepts and assessment of the gestational viability) and obstetric examinations (physical examination, inspection and abdominal palpation of the animal) from the $2^{\text {nd }}$ to the $8^{\text {th }}$ week. Six fetuses were observed during the ultrasound exams. On the $56^{\text {th }}$ day of pregnancy the patient presented pronounced abdominal distention, lethargy, anorexia and dyspnea. On physical exam, pale ocular and oral mucous membranes, dehydration and hypothermia $\left(35^{\circ} \mathrm{C}\right)$ were found. The obstetric examination revealed no alterations. Hemogram and ultrasound were carried out.

For the ultrasound exam, a Mylab VET 30 ultrasound scanner (Esaote, Italy) and a linear transducer $(7.5$ to $12 \mathrm{MHz})$ were used. Fetal heart rate, organs and tissue development and placental development were assessed. The fetal stress was not evident and the canine fetuses presented normal development. The hemogram revealed normocytic normochromic anemia and thrombocytosis $\left(760 \times 10^{3}\right.$ platelets).

After thorough clinical evaluation, the patient was submitted to cesarean section. Anesthesia was induced using propofol $(6 \mathrm{mg} / \mathrm{kg}$ IV) and maintained with isoflurane in $100 \%$ oxygen. The patient received parenteral fluid therapy following the surgical procedure. Non-steroidal anti-inflammatory and antibiotic therapies were established post-op. The neonates were taken to the intensive care unit for the initial appropriate management: placental waste removal in the neonates (especially in airway), evaluation of cardiac and respiratory rate (normal values were observed: heartbeat of 200 to 250 per minute and breaths of 10 to 18 per minutes) were previously heated (in 30 to $33^{\circ} \mathrm{C}$ ). Following complete recovery, a milk replacement based diet was given until the mother's complete convalescence period.

For the macroscopic assessment, placenta and fetal membranes were sampled during the Csection, fixed in $10 \%$ phosphate-buffered formalin solution ( $\mathrm{pH}$ 7.4). Slides were prepared in a routine fashion and the hematoxiline eosin staining technique was used.

\section{DISCUSSION}

According to the clinical findings verified on the bitch (pronounced abdominal distention, lethargy, anorexia, dyspnea, pale ocular and oral mucous membranes, dehydration and hypothermia) and observed on the hemogram (normocytic normochromic anemia and thrombocytosis) and ultrasound (presence of abnormal fluid accumulation within the fetal membranes, especially in the allantois) a suggested diagnosis of hydrallantois in the bitch and the conclusive diagnosis of hydrallantois was obtained following the cesarean section. During the surgical approach, adequate care was taken for optimal management of the neonates, according to methodology described previously (Domingos et al., 2008).

Clinical signs presented by the patient in our study were similar to the ones described in other case reports of hydrallantois in a bitch (Smith, 1972). The respiratory distress observed in both cases was probably related to the acute dilatation of the abdomen and compression of the diaphragm muscle.

The clinical signs observed (pale ocular and oral mucous membranes, dehydration and hypothermia) and the hemogram results 
(normocytic normochromic anemia and thrombocytosis) are similar to clinical conditions reported in other case reports on an equine patient (Christensen et al., 2006).

According to the ultrasound findings, the fetus presented cardiac frequency within the normal values and fetal stresses were not evident. It was found that the canine fetus presented normal development that was compatible with the estimated gestational age (56 days). The fetal intestinal peristalsis was also observed and no congenital or other alterations that could be lifethreatening were found, as reported in another trial (Feliciano et al., 2007). Therefore, fetal malformation was excluded as a possible cause of hydrallantois in the current case report.
The ultrasound exam revealed the presence of abnormal fluid accumulation within the fetal membranes, especially in the allantois, which was incompatible with the $8^{\text {th }}$ week of pregnancy in bitches. Comparing such finding to those observed on the $7^{\text {th }}$ week, it was noted that there was a remarkable increase in fluid within the fetal membrane (Figure 1). The normal finding during the last week of pregnancy in bitches is the relative reduction of intra-placental liquid, according to other studies (Nyland and Mattoon, 2005). Such alteration observed in the canine fetal membrane corroborates the findings in other studies in goats (Loi et al., 2006) and mares (Christensen et al., 2006) with hydrops of the fetal membrane.

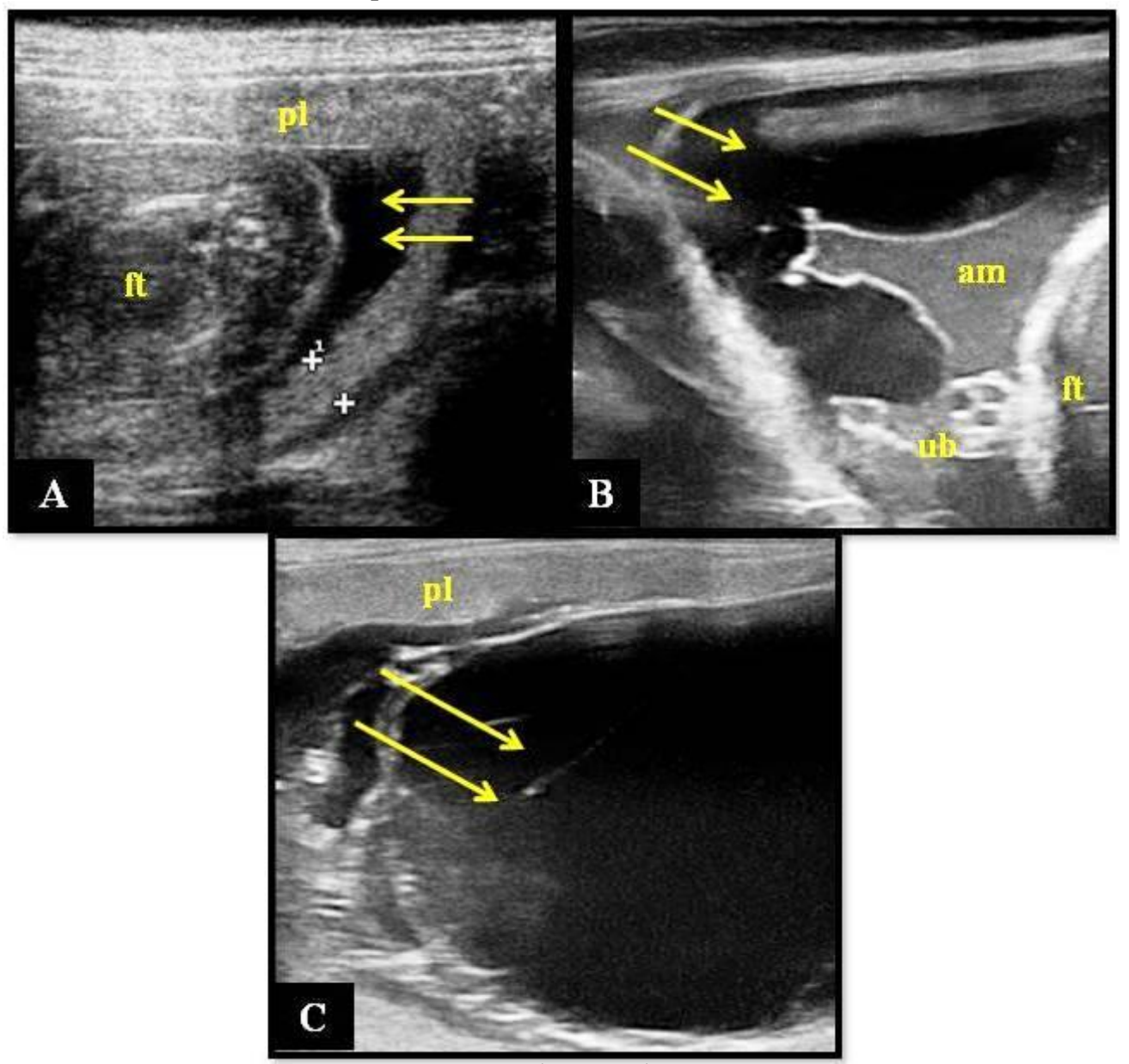

Figure 1. Mode-B ultrasound imaging of the $7^{\text {th }}$ and $8^{\text {th }}$ weeks of pregnancy in a Pug bitch with hydrallantois. (A) Presence of intra-placental fluid, which was compatible with the $7^{\text {th }}$ week of pregnancy (49 days) (arrows) and fetus (ft). (B) Note the amniotic (am) and umbilical (ub) areas and normal placentation ( $\mathrm{pl}$ ) and the presence of abnormal accumulation of intra-placental fluid in the de allantois area (arrows), during the $8^{\text {th }}$ week (56 days). (C) Note the accumulation of fluid in the allantois area (arrows). 
Regarding the macroscopic exam during the $\mathrm{C}$-section, distention of the fetal membranes and accumulation of fluid within the allantois was observed, as seen before during the ultrasound exam. About $20 \mathrm{~mL}$ of fluid per placenta was estimated, which is close to the values described in the case reported by Smith (1972).

According to the veterinary literature, the neonates from an abnormal uterine hydrops pregnancy may present congenital alterations and may sometimes be associated with a very short survival rate or life expectancy (Christensen et al., 2006). All neonates in our case report were normal at the initial physical exam and were carefully managed according the recommendations of other authors (Domingos et al., 2008). However, they died few days after birth, as mentioned in other studies (Christensen et al., 2006). The neonates died of unknown causes and it was not possible to perform the necropsies of the animals due to the owner's request.

Macroscopically, the placenta presented normal aspect and the histologic exam revealed a normal placenta. Several blood vessels were noted, which was a clear characteristic of normal mature placenta (Steiger et al., 2006). In some sites there was a lack of cohesion of the connective tissue, which suggested the presence of edema (Constant et al., 2006) (Figure 2). Such findings suggest the absence of histological alterations in cases of hydrallantois in bitches.

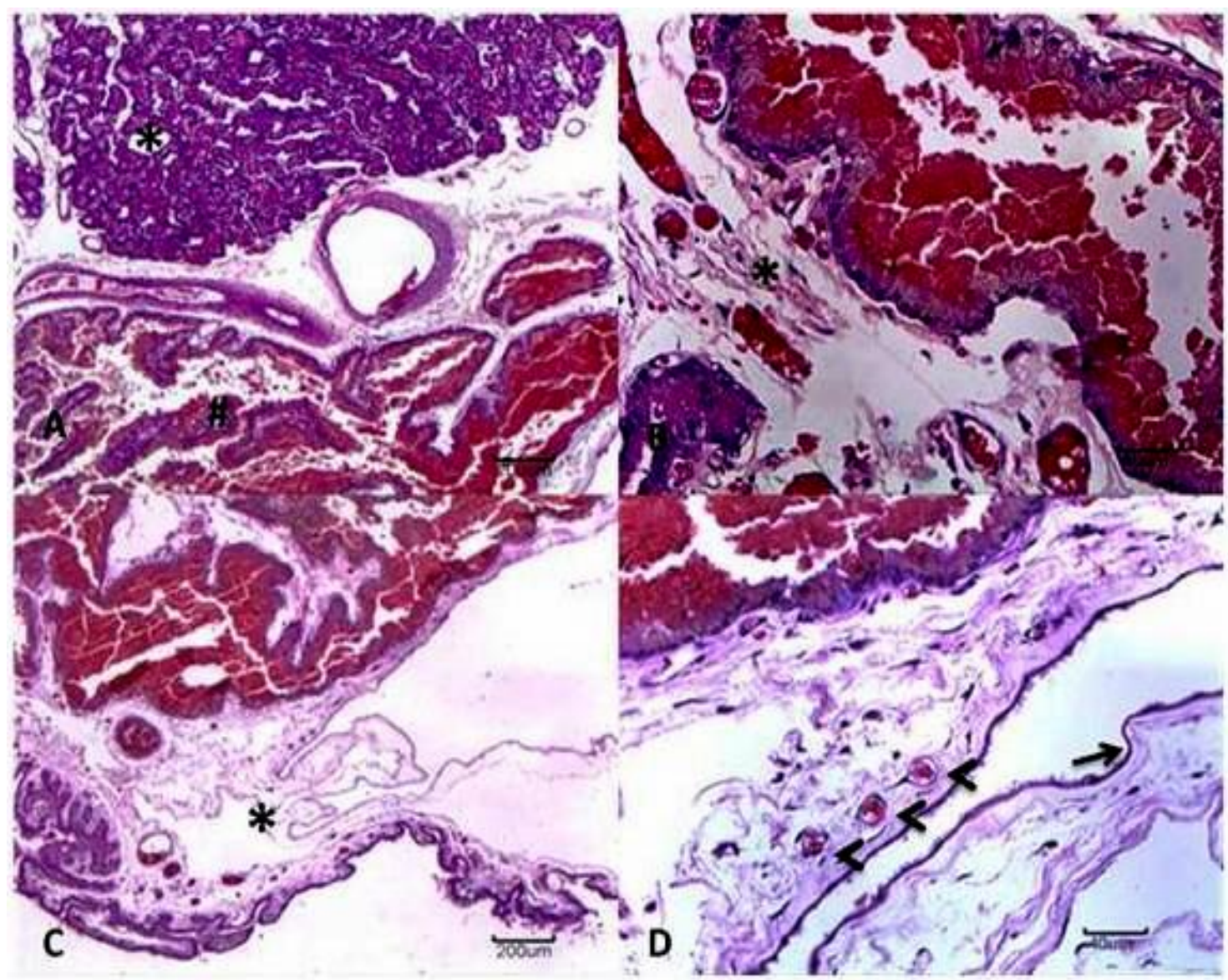

Figure 2. Diagram showing microscopic alterations on the placental and fetal membranes in a bitch with hydrallantois: A) canine placenta presenting fetal $(*)$ and maternal areas (\#), HE, bar $=200 \mu \mathrm{m}$; B) Note fraying of the connective tissue, suggesting the presence of edema (*), HE, bar $=40 \mu \mathrm{m}$; C) yolk sac insertion area $(*)$, HE, bar $=200 \mu \mathrm{m}$; D) details on the yolk sac. Note the epithelial formation (tip of the arrow) and formation of blood vessels (a), HE, bar $=40 \mu \mathrm{m}$. 


\section{CONCLUSION}

In conclusion, clinical and ultrasound assessment were suitable for the diagnosis of hydrallantois in a canine patient, which was confirmed and successfully treated by cesarean section.

\section{ACKNOWLEDGEMENTS}

The authors would like to thank FAPESP for the financial support for the current research and for post-doctorate scholarship support (processes 2010/16913-7 and 2011/06011-9).

\section{REFERENCES}

CHRISTENSEN, B.W.; TROEDSSON, M.H.T.; MURCHIE, T.A. et al. Management of hydrops amnion in a mare resulting in birth of a live foal. JAVMA, v.228, p.1228-1233, 2006.

CONSTANT, F.; GUILLOMOT, M.; HEYMAN, Y. et al. Large offspring or large placenta syndrome? Morphometric analysis of late gestation bovine placentomes from somatic nuclear transfer pregnancies complicated by hydrallantois. Biol. Reprod., v.75, p.122-130, 2006.

DOMINGOS, T.C.S.; ROCHA, A.A.; CUNHA, I.C.N. Basic care with pregnant and neonate canine and feline: review of literature. $J B C A$, v.1, p.94-120, 2008.

FELICIANO, M.A.R.; MUZZI, L.A.L.; LEITE, C.A.L. et al. Two-dimensional conventional, high resolution two-dimensional and threedimensional ultrasonography in the evaluation of pregnant bitch. Arq. Bras. Med. Vet. Zootec., v.59, p.1333-1337, 2007.
JACKSON, P.G.G. Problemas da gestação. In: JACKSON, P.G.G. (Ed). Obstetrícia Veterinária. 2.ed. São Paulo: ROCA, 2006. p.1741.

KUSTRITZ, M.V.R. Pregnancy diagnosis and abnormalities of pregnancy in the dog. Theriogenology, v.64, p.755-765, 2006.

LANDIM-ALVARENGA, F. Patologias da Gestação. In: PRESTES, N.C.; LANDIMALVARENGA, F. (Eds). Obstetrícia Veterinária. 1.ed. Rio de Janeiro: Guanabara Koogan S.A., 2006. p.130-158.

LOI, P.; CLINTON, M.; VACKOVA, I. et al. Placental abnormalities associated with post-natal mortality in sheep somatic cell clones. Theriogenology, v.65, p.1110-1121, 2006.

NYLAND, G.T.; MATTOON, J.S. Pregnancy diagnosis and fetal development. In: NYLAND, G.T.; MATTOON, J.S. (Eds). Veterinary Diagnostic Ultrasound. 3.ed. Philadelphia: W.B. Saunders Company, 2005. p.146-151.

OEHME, F.W. Hydrops allantois associated with twin pregnancy and uterine rupture in a cow. JAVMA, v.145, p.688-691, 1964.

SMITH, P.L. A case of hydriallantois in the bitch. Vet. Rec., v.91, p.24, 1972.

STEIGER, K.; POLITT, E.; HOEFTMANN, T. et al. Morphology of canine placental sites after induced embryonic or fetal death. Theriogenology, v.66, p.1709-1714, 2006. 